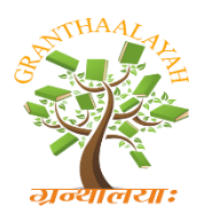

\author{
INTERNATIONAL JOURNAL OF RESEARCH - \\ GRANTHAALAYAH \\ A knowledge Repository
}

Science

\title{
OPTIMIZATION OF FATTY ACID GENERATION USING PARAMETRIC ANALYSIS
}

\author{
Harsha S *1, Shraddha Prashant Thakare ${ }^{2}$, A S Kulkarni ${ }^{3}$ \\ ${ }^{1}$ Associate Professor, Deaprtment of ISE, Jyothy Institute of Technology, Bengaluru, India \\ ${ }^{2}$ Junior Research Fellow, Energy Lab, CIIRC, Jyothy Institute of Technology, Bengaluru, India \\ ${ }^{3}$ Ex Professor, Department of Oil technology, Laxminarayan Institute of Technology, Nagpur,
} India

\begin{abstract}
The objective of this study is to optimize the different parameters to carry out analysis of fatty acids. A kinetic was observed for first order enzymatic hydrolysis of flax seed methyl ester was carried out by using Rhizomucor michei. In this study the analysis of hydrolysis was carried out by varying the temperature $\left(30-40^{\circ} \mathrm{C}\right)$ and enzyme load $(2-5 \%)$. The optimal condition were found to temperature $50^{\circ} \mathrm{C}, 6 \mathrm{~h}$ reaction time, buffer to flax seed methyl ester ratio $1.5: 1(\mathrm{v} / \mathrm{w})$ and $4 \%$ enzyme load to achieve a maximum hydrolysis conversion of $97.56 \%$. The effect of temperature on the reaction rate constant and equilibrium constant has been determined using Arrhenius equation. The heat of reaction was found $14.516 \mathrm{KJ} / \mathrm{mol}$. Taguchi's design of experiment $\mathrm{L}_{16}$ and $\mathrm{L}_{9}$ orthogonal array was performed to optimize hydrolysis reaction conditions. Rate of reaction, effect of temperature, enzyme modifier, $\mathrm{pH}$ and oil to buffer ratio were considered as a primary influencing parameters which effects the percentage of hydrolysis and fatty acid formed. From the analysis of variance, the influencing parameters on production of fatty acid were reaction time and enzyme modifier. The predicted conversion was found in good rectification with experimental values having $R^{2}=0.9945$ and $R^{2}=0.983$. Maximum fatty acid formed was $98.76 \%$ from methyl ester and $98.92 \%$ from oil.
\end{abstract}

Keywords: Hydrolysis; Kinetics; Flax Seed Oil; Flax Seed Methyl Ester; Optimization; Taguchi Method.

Cite This Article: Harsha S, Shraddha Prashant Thakare, and A S Kulkarni (2019). "OPTIMIZATION OF FATTY ACID GENERATION USING PARAMETRIC ANALYSIS." International Journal of Research - Granthaalayah, 7(6), 120-131. https://doi.org/10.5281/zenodo.3262206.

\section{Introduction}

The polyunsaturated (PUFAs) are the essential nutrients for human health. Long chain polyunsaturated fatty acids such as docosahexaenoic acid (DHA) and eicosatetraenoic acid (EPA) are the most important structural components of cell membranes in kidney, retina, liver, vital 
tissues of brain and play an important role in maintenance of structural integrity of the cell membranes.[1][2] Recently there has been a growing survey in the biological properties of flax and its beneficial effect on coronary heart disease and hormonal disorders[3].

Oils and fats are triglycerides and their hydrolysis involves reactions with water to produce valuable free fatty acids and glycerol. Fatty acids play very important role in naturally produced renewable raw materials which includes oils from vegetable origin. Manufacturing of high-value product such as lubricating oils, adhesives, coating and cosmetics require huge amount of fatty acids. There are mainly three methods of hydrolysis of oil in the production of fatty acids involves: high pressure steam splitting, enzymatic hydrolysis and alkaline hydrolysis. [4]

Enzymatic hydrolysis of triglycerides may be carried out at ambient conditions and making it energy efficient process as compare with other process [4]. In order to maximize the conversion of yield of esters, attention was given to the optimization of the system parameters (such as enzyme concentration and temperature [5]. The formation of water present in the reaction problem in hydrolysis reaction as it favors the reverse[6]. Use of enzymatic hydrolysis has main technical advantage such as economic, ecological, toxicological and environment free [7].

The previous investigations reveal a merge study on the hydrolysis of flax seed oil or flax seed methyl ester for preparation of fatty acids such as alpha linolenic fatty acid; the literature shows the information on the hydrolysis of flax seed oil using different enzymes. Banin Rupani et al. [1] mentioned that Candida rugosa lipase reacted with triglycerides by hydrolysis process resulted in fatty acids that was enriched in alpha linolenic to about $72 \%$ and further reached to $80 \%$. It was observed that concentration of linolenic acid in the product mixture increased from 50.45 to 72.33\%. Candida rugosa lipase showed maximum hydrolysis percentage while Rhizomucor michei showed the minimum hydrolysis of flax seed oil. Patricia de O. et al (2009) [8] studied the hydrolysis of acylglycerol using three kinds of native microbial lipases (Aspergillus niger, Rhizopus javanicus and Penicillium solitum). The optimum conditions were enzyme concentration of $500 \mathrm{U} / \mathrm{g}$ oil, reaction temperature of $45 \mathrm{oC}$ and water/oil mass rate $2: 1(\mathrm{~m} / \mathrm{m})$ after $24 \mathrm{~h}$ reaction which gives the degree of hydrolysis $60 \%$ led to an increase the docosahexaenoic acid (DHA)[11].

Akhila Rajan et al. (2013) [9] used the novel alkaline lipase from Aspergillus fumigates MTCC 9657 for removal of unwanted fatty acids and enrichment of $\omega-3$ fatty acids. The free fatty acid content was slightly increased after 4 hours and it continued up to the end of the process. It was clearly mentioned that enzyme was active for $12 \mathrm{~h}$ and free fatty was increased from 0.02 to $15 \%$. Sulaiman Al-Zuhair et al. (2013) [13] investigated the kinetics of the enzymatic hydrolysis of palm oil using in a batch reactor. Shau-Wei Tsai et al. (1991) [14] examined the optimal conditions using the lipase-catalyzed hydrolysis of high concentration olive oil in biphasic isooctane-aqueous system. The maximum equilibrium conversion was attained higher than $98 \%$ for $0.1 \mathrm{~g} / \mathrm{mL}$ olive oil.

Generally alpha linolenic acid is present in flax seed oil (50-52\%) which can be obtained through hydrolysis. Because of the off flavor and rancidity flax seed oil is not used as a cooking oil in India. As per the literature the study was carried out on the hydrolysis of flax seed oil. In the present study a novel method was developed for the enzymatic hydrolysis of flax seed oil methyl ester as a substrate. The kinetics for enzymatic hydrolysis [12] of flax seed oil methyl ester is examined 
the influence of experimental parameters like reaction temperature, time and enzyme concentration using immobilized lipase Rhizomucor michei as a catalyst. Taguchi method was used to design the best model.

\section{Materials and Methods}

\subsection{Materials}

Flax seed methyl ester used in the experiments was $100 \%$ pure with a saponification value of $193.82 \mathrm{mg} \mathrm{KOH} / \mathrm{gm}$. Lipozyme RMIM (Rhizomucor michei) was obtained from Novozyme A/S, Krogshoejvej 36-2880 Bagsvaerd, Denmark. All the chemicals as methanol, ethyl acetate, potassium hydroxide and phenolphthalein indicator were of analytical grade procured from M/s. Sd Fine Chem. Pvt. Ltd., Mumbai. A phosphate buffer of $7.5 \mathrm{pH}$ was prepared in the laboratory.

\subsection{Methods}

The fatty acids composition of flax seed methyl ester was analyzed using a Gas Chromatograph Agilent 6890 series equipped with a flame ionization detector in accordance with the AOCS official method Ce le-91. The stationary phase used was a capillary column, DB-225 MS (i.d. $0.25 \mathrm{~mm}$, length $30 \mathrm{~m}, 0.5 \mu \mathrm{m}$ ). The oven temperature from 150 to $300 \mathrm{oC}$ at $5 \mathrm{oC}$ per minute with nitrogen at a flow rate of $35 \mathrm{~mL}$.min-1. The injector and detector temperature was programmed from $160 \mathrm{oC}$ for $2 \mathrm{~min}$ and $230 \mathrm{oC}$ at $5 \mathrm{oC}$ per minute and held at this temperature for $20 \mathrm{~min}$. The carrier gas used was nitrogen with a flow rate of $1 \mathrm{~mL} \mathrm{min-1.} \mathrm{The} \mathrm{injector} \mathrm{and} \mathrm{detector} \mathrm{temperature}$ were maintained at 230 and $270 \mathrm{oC}$ respectively. The area percentage was recorded using an HP Chem Station Data System. The methyl ester was found to be $100 \%$ pure. Acid value and Saponification value were determined as per AOCS official method Cd 3-25 (AOCS 2004a and AOCS 2004b).

\section{Method for Preparation of Flax Seed Methyl Ester}

Transesterification [21] of flax seed oil was carried out in presence of 1\% $\mathrm{H} 2 \mathrm{SO} 4$ and methanol under condensation at temperature of $60 \mathrm{oC}$ for a reaction time $3 \mathrm{~h}$. The samples were drawn at regular interval of time and monitoring the progress of the reaction by determining the thin layer chromatography (TLC). The fatty acids compositions were analyzed by Gas Chromatography. The acid value of the product sample was found to be 0.1034 .

\subsection{Experimental Procedure}

Hydrolysis of flax seed methyl ester was carried out using Rhizomucor michei in presence of phosphate buffer $(1.5: 1)(\mathrm{v} / \mathrm{w})$. The reaction mixture was incubated at $50 \mathrm{oC}$ for $6 \mathrm{~h}$. Samples were drawn at regular time intervals to check the progress of the reaction. After that sample was filtered by filter paper, neutralized with water, dried and analyzed. The amount of fatty acid in the product was estimated by the calculating the acid value. $0.5 \mathrm{~g}$ of sample obtained by hydrolysis reaction were subjected to titration against a $0.1 \mathrm{~N} \mathrm{KOH}$ solution and acid value was calculated. This acid value was used to calculate the percentage hydrolysis. 
The percentage hydrolysis was tabulated using the following formula.

$\%$ Hydrolysis $=\frac{\mathrm{AV} \text { of product }-\mathrm{AV} \text { of methyl ester }}{\mathrm{SV} \text { of methyl ester }-\mathrm{AV} \text { of methyl ester }} \times 100$

Eq. 1

Where AV is the acid value and SV is the saponification value. Different sets of experiments were carried out with the help of several operating conditions. The first set of experiment were carried out by varying time from $30 \mathrm{~min}$ to $6 \mathrm{~h}$, while the other parameters remain constant i.e. $4 \%$ enzyme modifier, buffer to flax seed methyl ester $1.5: 1(\mathrm{v} / \mathrm{w})$ and temperature at $50 \mathrm{oC}$. A second set of experiment was carried out by varying temperature range 30 to $60 \mathrm{oC}$, while maintaining other parameters constant i.e. $4 \%$ enzyme load and buffer to flax seed methyl ester ratio 1.5:1(v/w), time period of $6 \mathrm{~h}$. The third set of experiment was conducted at varying enzyme concentration from 2 to $5 \%$ by keeping a same buffer to flax seed methyl ester ratio $1.5: 1(\mathrm{v} / \mathrm{w})$ at $60 \mathrm{oC}$.

\subsection{Statistical Analysis}

The experiment was carried out in duplicate for experimental error estimation and the data was analyzed by a paired student's t-test to evaluate the level of statistical significance. A p-value < 0.05 was considered significance. A p-value of 0.0006 was estimated which was considered as significance.

\subsection{Kinetic Model}

For this reaction system, first order reversible model was considered (Knezevic et al. 1998). The reaction mechanism for the kinetic model involving reversible reaction is as follows:

$\mathrm{A}+\mathrm{B} \Leftrightarrow \mathrm{C}+\mathrm{D}$

The rate of reaction is expressed as:

$r_{A}=-\frac{d C_{A}}{d t}=k_{1} C_{A}-k_{2} C_{c} C_{D}$

where $\mathrm{CA}, \mathrm{CC}$ and $\mathrm{CD}$ denote the concentration of methyl ester, concentration of mixture of fatty acid and concentration of methanol formed during the reaction, respectively. $\mathrm{CB}$ is the concentration of water which was not considered for the developing the kinetic model. $\mathrm{k} 1$ and $\mathrm{k} 2$ are kinetic rate constants for the forward and backward reactions, respectively.

$\frac{d X_{A}}{d t}=k 1\left(1-X_{A}\right)-k_{2} C_{A O} X_{A}^{2}$

At equilibrium, $\frac{d X_{A}}{d t}=0$ and $\mathrm{XA}=\mathrm{XE}$, and from Eq.4, we get:

$k_{2}=\frac{k_{2}\left(1-X_{A}\right)}{C_{A 0}-X_{E}^{2}}$ 
By substituting the value of $\mathrm{k} 2$ in Eq. 4 and rearranging the terms, we get:

$\frac{d X_{A}}{d t}=\frac{k_{1}}{X_{E}^{2}}\left[\left(X_{E}-1\right) X_{A}^{2}-X_{E}^{2} X_{A}+X_{E}^{2}\right]$

Eq. 6

Integrating of Eq. 6 yields and we get:

$$
\ln \left[X_{A}-X_{E}\right]-\ln \left[X_{A}\left(X_{E}-1\right)-X_{E}\right]=\frac{\left(X_{E}-2\right)}{X_{E}} k_{1} t
$$

The conversion as a function of time can be deduced from Eq. 7 as follows:

$$
X_{A}=\frac{X_{E}\left(1-e^{\beta t}\right)}{\left[1-X_{A} e^{\beta t}+e^{\beta t}\right]}
$$

Where $\beta=[\mathrm{k} 1 *(\mathrm{XE}-2) / \mathrm{XE}]$

Rearranging the terms gives rate constant.

$$
k_{1}=\frac{\beta X_{E}}{\left(X_{E}-2\right)}
$$

\subsection{Design of Experiment}

Taguchi method [15] is a robust design of experiment [17] method which works on the basis of orthogonal array. It provides the fewest experiments which will give maximum information about influencing parameters present on the system. The experimental results are represented in the terms of signal-to-noise $(\mathrm{S} / \mathrm{N})$ ratio. There are three categories of quality characteristic in the analysis of $\mathrm{S} / \mathrm{N}$ ratio, i.e. the-lower-the-better, the-higher-the-best, and the nominal-the-better. Therefore the optimum condition of the process parameter is the level having the greatest $\mathrm{S} / \mathrm{N}$ ratio. A statistical analysis of variance (ANOVA)[16] is carried out to identify which process parameters are statistically significant.

\subsubsection{Optimization of Percentage Hydrolysis of Flax Seed Methyl Ester Varying the Parameters}

\section{Selection of the injecting parameters and their levels (flax seed methyl ester)}

In the present study, the experiments were incubated in the $50 \mathrm{ml}$ round bottom flask. The maximum percent hydrolysis was defined by varying the process parameters, i.e. temperature in the range $30-60 \mathrm{oC}$, enzyme load in the range $2-4(\mathrm{wt} \%)$, reaction time in the range $2-8$ hour, flax seed oil to aqueous ratio in the range 1:0.25-1:2(v/w) and $\mathrm{pH}$ in the range 5-8. 
Table1: Experimental results for percentage hydrolysis and $\mathrm{S} / \mathrm{N}$ ratio

\begin{tabular}{|c|c|c|c|c|c|c|c|c|}
\hline Run & $\mathbf{A}$ & B & C & D & $\mathbf{E}$ & $\begin{array}{c}\% \\
\text { Hydrolysis }\end{array}$ & $\begin{array}{c}\text { S/N } \\
\text { RATIO }\end{array}$ & Mean \\
\hline & Temperature & $\begin{array}{c}\text { Enzyme } \\
\text { load }\end{array}$ & $\begin{array}{c}\text { Reaction } \\
\text { time }\end{array}$ & $\begin{array}{c}\text { Methyl } \\
\text { ester- } \\
\text { aqueous } \\
\text { ratio } \\
\end{array}$ & $\mathbf{p H}$ & & & \\
\hline 1 & 1 & 1 & 1 & 1 & 1 & 87.09 & 38.7994 & 87.09 \\
\hline 2 & 1 & 2 & 2 & 2 & 2 & 91.54 & 39.2322 & 91.54 \\
\hline 3 & 1 & 3 & 3 & 3 & 3 & 95.98 & 39.6436 & 95.98 \\
\hline 4 & 1 & 4 & 4 & 4 & 4 & 98.79 & 39.8943 & 98.79 \\
\hline 5 & 2 & 1 & 2 & 3 & 4 & 95.72 & 39.6201 & 95.72 \\
\hline 6 & 2 & 2 & 1 & 4 & 3 & 94.20 & 39.4810 & 94.20 \\
\hline 7 & 2 & 3 & 4 & 1 & 2 & 92.96 & 39.3659 & 92.96 \\
\hline 8 & 2 & 4 & 3 & 2 & 1 & 91.44 & 39.2227 & 91.44 \\
\hline 9 & 3 & 1 & 3 & 4 & 2 & 90.08 & 39.0926 & 90.08 \\
\hline 10 & 3 & 2 & 4 & 3 & 1 & 88.70 & 38.9585 & 88.70 \\
\hline 11 & 3 & 3 & 1 & 2 & 4 & 98.11 & 39.8343 & 98.11 \\
\hline 12 & 3 & 4 & 2 & 1 & 3 & 96.72 & 39.7103 & 96.71 \\
\hline 13 & 4 & 1 & 4 & 2 & 3 & 92.74 & 39.3453 & 92.74 \\
\hline 14 & 4 & 2 & 3 & 1 & 4 & 96.75 & 39.7130 & 96.75 \\
\hline 15 & 4 & 3 & 2 & 4 & 1 & 89.70 & 39.0558 & 89.70 \\
\hline 16 & 4 & 4 & 1 & 3 & 2 & 93.71 & 39.0558 & 93.71 \\
\hline
\end{tabular}

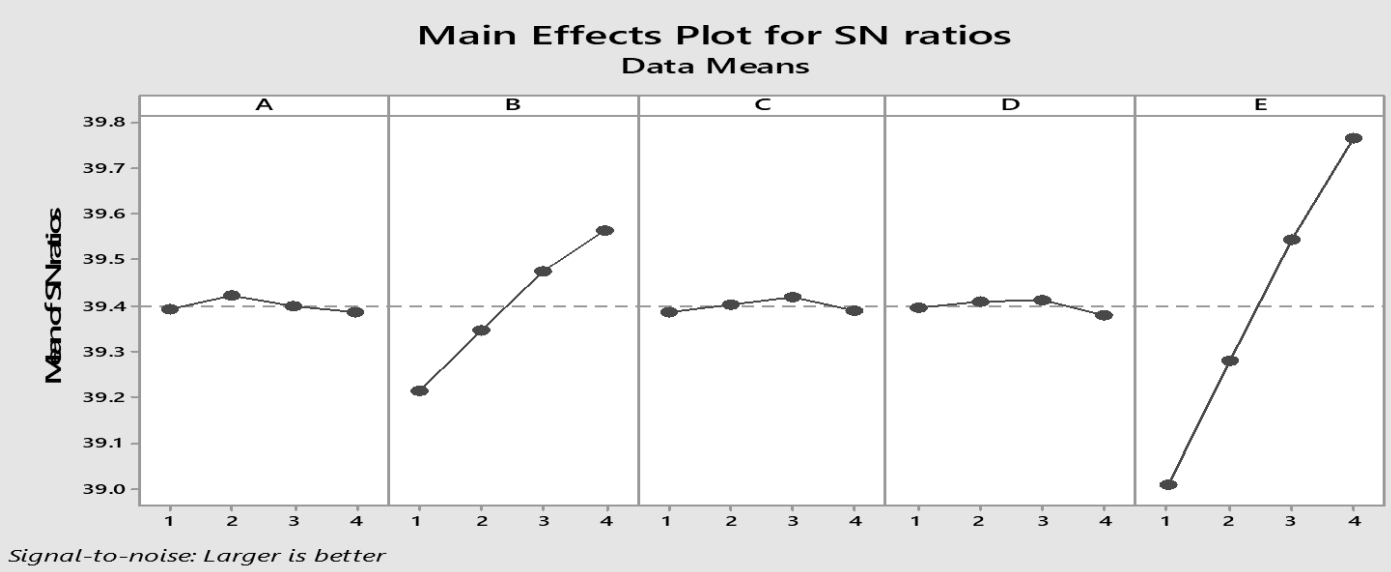

Figure1: S/N ratio graph 


\section{Development of Regression Model}

The complete design matrix of the experiments coupled with the experimental yield, $\mathrm{S} / \mathrm{N}$ ratio and mean was shown in Table 1. The Minitab 17 was generated the best fitted model as shown in Table 2. According to the sequential model sum of square, ........The regression model equation representing the effect of temperature, enzyme load, reaction time, buffer to methyl ester ratio and $\mathrm{pH}$ in terms of their levels, is given as,

$\%$ Conversion $=83.643-0.0553 \mathrm{~A}+1.2662 \mathrm{~B}+0.0202 \mathrm{C}-0.0492 \mathrm{D}+2.7167 \mathrm{E}$

The value of regression of determination R2 for the above equation is 0.9945 . The regression model explained $99.45 \%$ of the total variability in percent hydrolysis conversion.

Analysis of variance (ANOVA) was further carried out to determine the significance and the fitness of the linear model.

Table 2: Sequential model sum of squares

\begin{tabular}{|l|l|l|l|l|l|}
\hline Source & DF & $\begin{array}{l}\text { Adj. Sum of } \\
\text { Square }\end{array}$ & $\begin{array}{l}\text { Adj. Sum of } \\
\text { square }\end{array}$ & $\begin{array}{l}\text { F- } \\
\text { Value }\end{array}$ & $\begin{array}{l}\text { P- } \\
\text { Value }\end{array}$ \\
\hline Regression & 5 & 179.800 & 35.960 & 358.55 & 0.000 \\
\hline Temperature & 1 & 0.061 & 0.061 & 0.61 & 0.453 \\
\hline Enzyme Load & 1 & 32.068 & 32.068 & 319.74 & 0.000 \\
\hline Reaction Time & 1 & 0.008 & 0.008 & 0.08 & 0.781 \\
\hline $\begin{array}{l}\text { Methyl ester and buffer } \\
\text { ratio }\end{array}$ & 1 & 0.049 & 0.048 & 0.48 & 0.503 \\
\hline pH & 1 & 147.615 & 147.615 & 1471.82 & 0.000 \\
\hline Error & 10 & 1.003 & 0.100 & & \\
\hline
\end{tabular}

\section{Confirmation Test}

The confirmation test is used to verify estimated result compare with the experimental results. If the optimal combination of parameter and their levels coincidently match with one the experiment in the orthogonal then the confirmatory test is not required.

Confirmation test was required in the present study because combination A2B4C3D3E4 did not correspond to any experiment of the orthogonal array. One set of experiment at an optimal combination of parameter and their levels i.e. A2B4C3D3E4 was produced on the same method and from the same material. Percent error was calculated by using following formula.

$\%$ Error $=\frac{\text { Theoretical Value-Experimental Value }}{\text { Theoretical Value }} \times 100$

Table 3: Result from confirmation experiments

\begin{tabular}{|l|l|l|l|}
\hline \multirow{2}{*}{} & \multicolumn{3}{|l|}{ Optimum Condition } \\
\cline { 2 - 4 } & Estimated & Experiment & Difference \\
\hline Level & A1B4C4D4E4 & A2B4C3D3E4 & - \\
\hline \% Hydrolysis & 98.79 & 98.92 & 0.1315 \\
\hline
\end{tabular}




\section{Results and Discussion}

\subsection{Effect of Reaction}

The rate of hydrolysis of the reaction depends on the reaction time. Reaction time was optimized by keeping experiments at an enzyme concentration of $4 \%, 50 \mathrm{oC}$, buffer to flax seed methyl ester 1.5:1(v/w). Figure shows a linear plot as a function of conversion and reaction rate. From figure it can be concluded that reaction proceeds faster during the initial 30min and conversion increases as the reaction time increased. The most suitable period for the hydrolysis of flax seed methyl ester was found to be $6 h$.

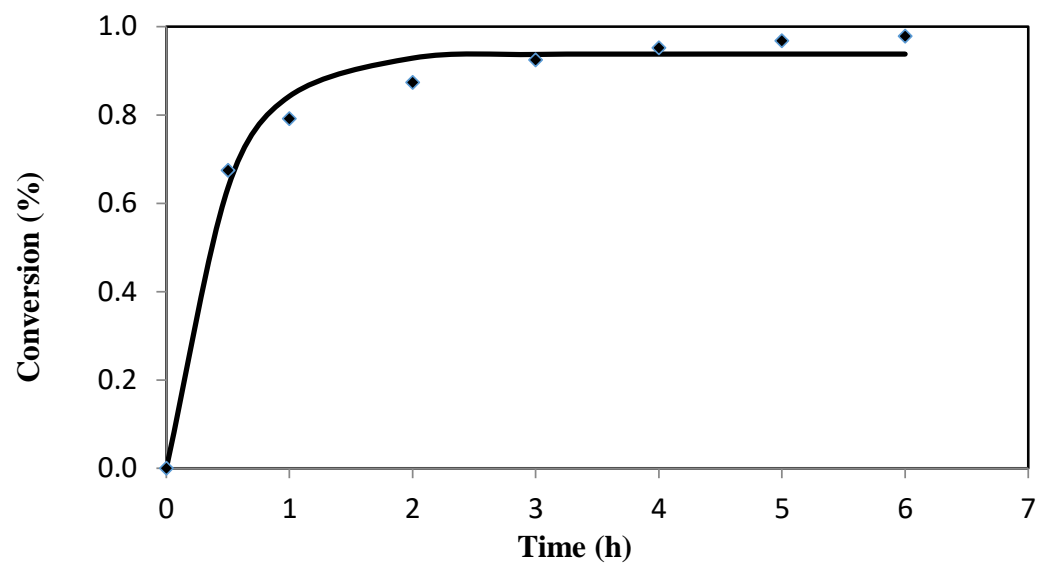

Figure 2: Effect of rate of reaction on hydrolysis of flax seed methyl ester.(Reaction temperature

$60 \mathrm{oC}$, enzyme concentration $4 \%$, buffer to flax seed methyl ester ratio of $1.5: 1(\mathrm{v} / \mathrm{w})$ )

$\checkmark$ experimental values ---model values

\subsection{Effect of Enzyme Load}

Generally, lipase catalyzed reaction take place at the interface, and the amount of enzyme available at the interface is very important. To determine the effect of enzyme on the system, the enzyme concentration was varied from 2 to $5 \%$ with buffer to methyl ester ratio $1.5: 1(\mathrm{v} / \mathrm{w})$ at $50 \mathrm{oC}$ for 6 $\mathrm{h}$. The effect of enzyme on the given process is shown in figure. When the enzyme concentration was $2 \%$ the conversion was $89.45 \%$, at $4 \%$ enzyme load, the conversion was $97.74 \%$. A further increase in enzyme concentration to $5 \%$ did not yield any further increase in conversion. Hence this value was considered as optimum condition.

\subsection{Effect of Reaction Temperature}

The temperature effect on the hydrolysis reaction at $4 \%$ enzyme concentration, buffer to methyl ester 1.5:1(v/w) and $6 \mathrm{~h}$ reaction time is shown in Figure. It was concluded that the reactant temperature increases the conversion rate also increases. At $30 \mathrm{oC}$, the conversion was $80.78 \%$ and as the temperature increases the conversion also increases at $40 \mathrm{oC}$, the conversion $89.42 \%$, a maximum conversion reached at $50 \mathrm{oC}, 97.41 \%$ was measured. A further increase in the temperature $60 \mathrm{oC}$, there was sudden fall on conversion to $85.43 \%$. 


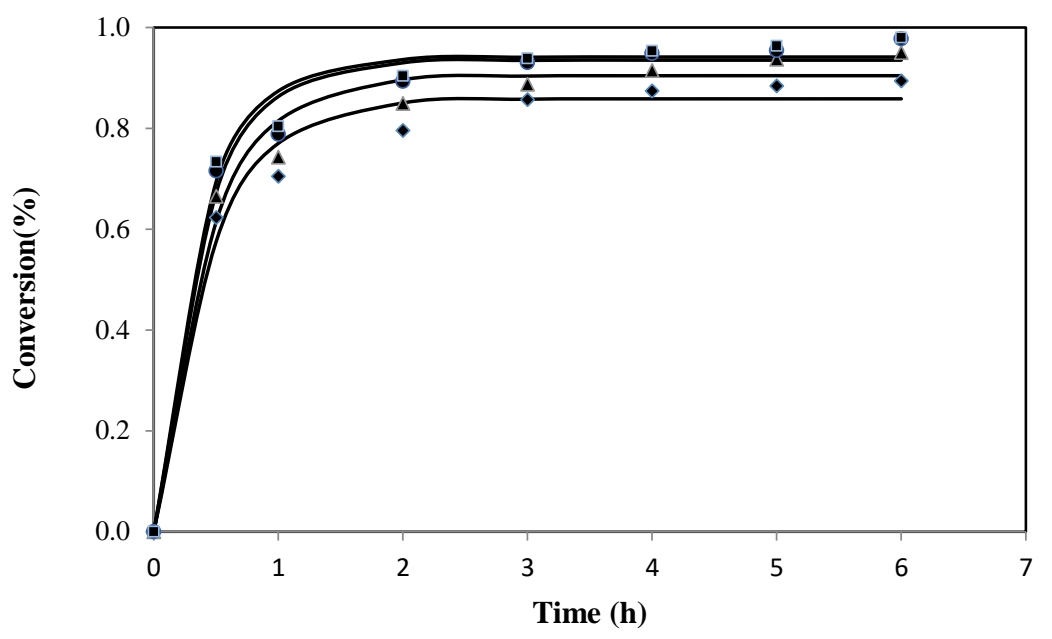

Figure 3: Effect of enzyme concentration on hydrolysis of flax seed methyl ester.

(Reaction time $6 \mathrm{~h}$, buffer to methyl ester ratio of $1.5: 1(\mathrm{v} / \mathrm{w})$, temperature $60 \mathrm{oC}$ )

$\bullet 2 \% \Delta 3 \%$ - $4 \% \cdot 5 \%---$ model values

\subsection{Applying the Kinetic Model}

The derived kinetic model equation for first order reversible reaction was fitted to the experimental data and the two parameters, Xe and $\beta$ of Eq.9 were determined by non linear regression with a Levenberg-Marquardt[19] algorithm using statistical software. A regression co-efficient value is 0.969 , it seems model is statistically significant and inter predict the relationship between the experimental and theoretical parameters. The values of rate constant $\mathrm{k} 1$ and $\mathrm{K} 2$ for the forward reaction and backward reaction was calculated from Eq.10 and Eq.5 respectively. The results obtained for the rate constants and the equilibrium conversion have been tabulated in Table 3 .

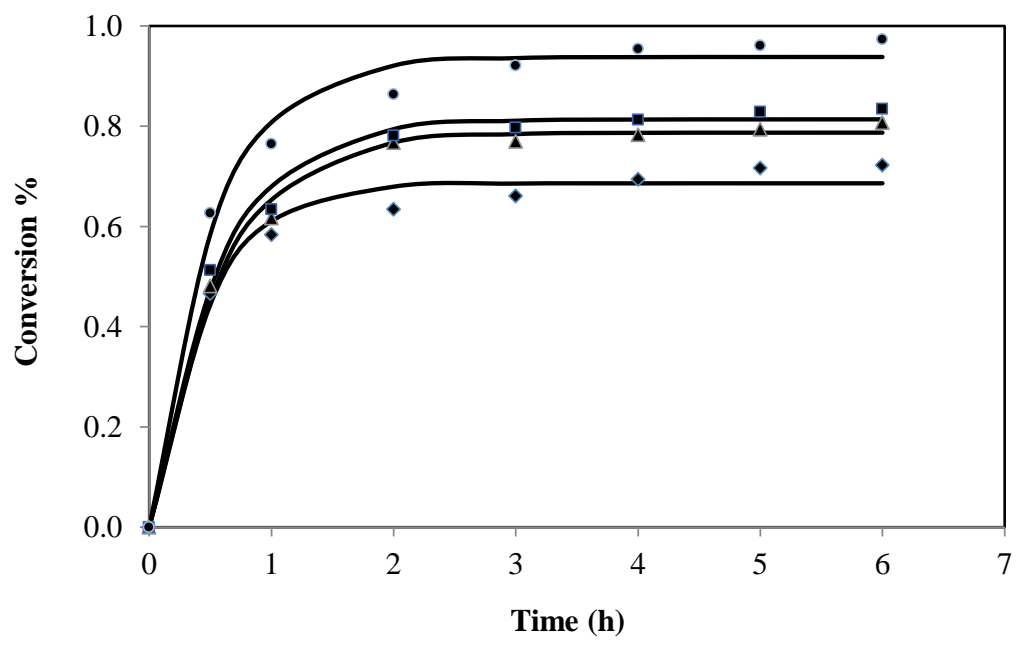

Figure 4: Effect of rate of reaction on hydrolysis of flax seed methyl ester.

(Reaction temperature $60 \mathrm{oC}$, enzyme concentration $4 \%$, buffer to flax seed methyl ester ratio of $1.5: 1(\mathrm{v} / \mathrm{w}))$

- experimental values ---model values 
Table 4: Equilibrium conversion, kinetic rate constants and equilibrium constant for the hydrolysis of methyl ester at different reaction temperatures

\begin{tabular}{|l|l|l|l|l|}
\hline Temperature(oC) & Xe & k1 & k2 & K \\
\hline 30 & 0.78715 & 1.253479 & 0.671094 & 1.867816 \\
\hline 40 & 0.84637 & 1.590571 & 0.511203 & 3.111427 \\
\hline 50 & 0.93814 & 1.78824 & 1.195177 & 1.496214 \\
\hline 60 & 0.81886 & 1.457673 & 0.72494 & 2.01075 \\
\hline
\end{tabular}

The effect of temperature on the forward reaction rate constant was obtained by keeping $\mathrm{k} 1$ to the Arrhenius equation (Eq.11 and Eq. 12).

$$
k=A e^{\left[\frac{-\Delta E}{R T}\right]}
$$

And

$$
\ln k_{1}=\frac{-\Delta E}{R T}+\ln A
$$

For forward reaction, rate constant $\mathrm{k} 1$ is calculated using Eq.10. From the plot of $\operatorname{lnk} 1$ as a function of the reciprocal temperature, as shown in Figure 5, for 4\% enzyme concentration, the frequency factor, A, and the energy of activation, $\Delta \mathrm{E}$, were formed to be $0.404 \times 103$ and $14.516 \mathrm{KJ} / \mathrm{mol}$, respectively.

The fitting of the experimental data to the proposed model is also assessed by comparing the experimental conversion values with the theoretically predicted conversions using Eq.7, and is presented in Figure.5. A good agreement between the experimental conversion and values calculated from Eq. 7 was absorbed. Since the p-value for the model was lower than 0.05 there was statistical relation between the response and the selected variables at $95 \%$ confidence level. It can be inferred that the proposed model represented the present reaction system satisfactorily.

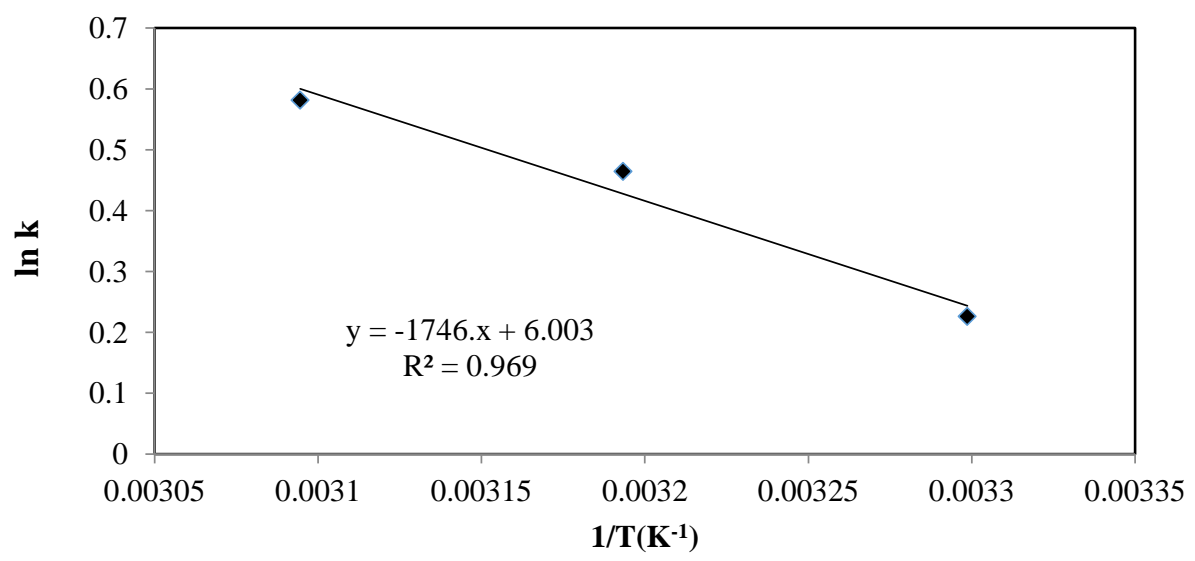

Figure 5: Effect of reaction temperature on reaction rate constant 


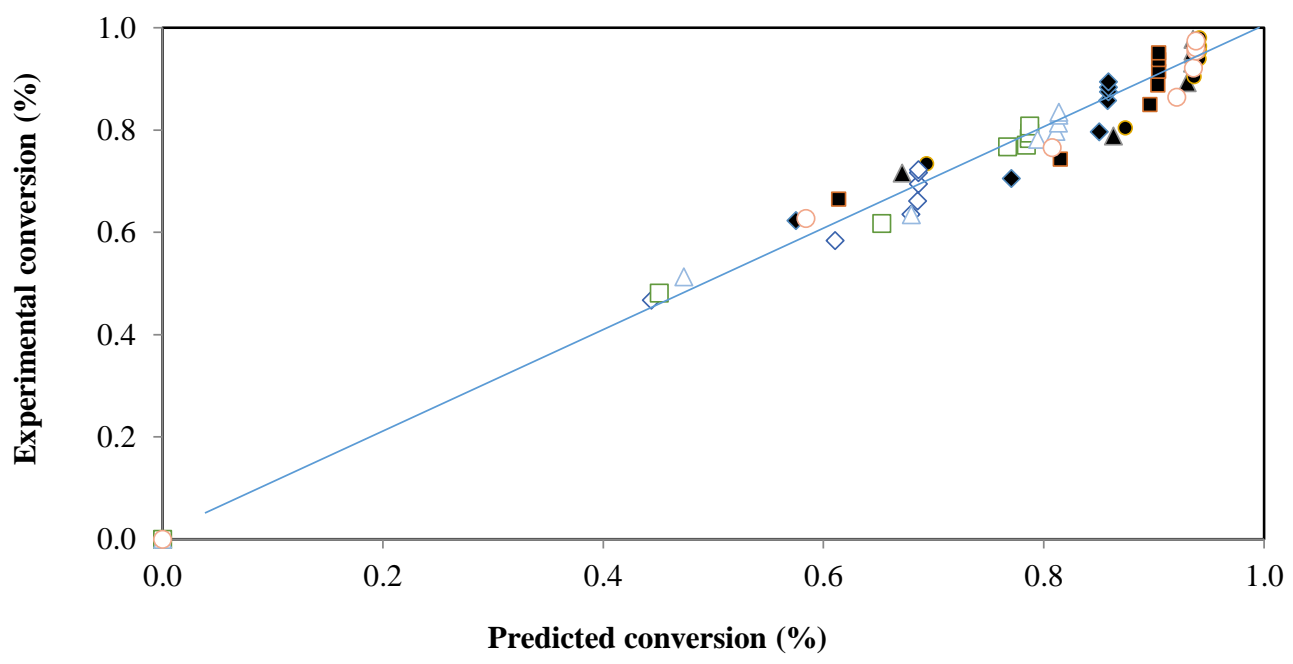

Figure 6: Comparison of experimental and predicted conversion

\section{Conclusion}

The experimental results and the analysis of the same has clearly shown that, the predicted values match closely with the observed values of fatty acid generation using the proposed optimization method. The results depicted in Figure 6 show the correlation between the predicted and observed conversion percentages. It is evident that the major contributing parameters for the conversion percentage are reaction time and enzyme modifier. Controlling the same as per requirement will always yield the necessary volume of fatty acids with a considerable accuracy. Thus it can be concluded that the proposed method of optimization fares well in controlled environment for production of fatty acids.

\section{Acknowledgements}

The authors whole heartedly thank the Centre for Incubation, Innovation, Research and Consultancy (CIIRC) and Sri Sharada Peetham, Sringeri for the support extended towards this endeavor.

\section{References}

[1] Rupani, B., K. Kodam, R. Grade and G. D. Najafpour, 2012. Lipase-mediated hydrolysis of flax seed oil for selective enrichment of $\alpha$-linolenic acid. Eur. J. Lipid Sci. Technol., 114: 1246-1253.

[2] Schuchardt, J.P., M. Huss, M., Stauss-Grabo and A. Hahn, 2010, Significance of long-chain polyunsaturated fatty acids (PUFAs) for the development and behavior of children., Eur. J. Pediatr., 169: 149-164.

[3] Bailey's Industrial oil and fat products, sixth edition, volume 1, edible oils and fat products, chemistry, properties and health effects. Edited by Fereidoon Shahidi. Wiley Interscience. A John Wiley and sons, Inc. publications 2005

[4] FOOD FATS AND OILS Institute of Shortening and Edible Oils 1750 New York Avenue, NW, Suite 120 Washington, DC 20006. Ninth Edition. 
[5] Patrick Adlerqreutz, Bengt Danielsson, Pre-Olof Larsson, Mats-Olle Mdnsson and Kumaran Ramanathan,2004."Enzyme Technology", Pure and Applied biochemistry and Biotechnology,Lund University.

[6] Y. Ali, M.A. Hanna, and S.L. Cuppett, "Fuel properties of tallow and soybean oil esters", Journal of the American Oil Chemists Society, $72(12), 1557$ (1995).

[7] Rahul D. Gorle, Diwesh B. Meshram, Pratik L. Naik, Vivek S. Narnaware, 2013. Optimization of effective parameter of jatropha biodiesel using taguchi method and performance analysis using CI engine, International Journal of Innovative Technology and Exploring Engineering, vol 3, issue-5.

[8] Patricia de O. Carvalho, Paula R.B. Campos, Maximiliano D'Addio Noff, Patricia B. L. Fregolente, Leonaro V. Frigolente, 2009. Enzymatic hydrolysis of Salmon oil by native lipases: optimization of process parameters. J. Braz. Chem. Soc., vol. 20 no. 1.

[9] Akhila Rajan, Dasiah R. Sobankumar and Ananthkrishnan J.Nair, 2014. Enrichment of $\omega-3$ fatty acids in flax seed oil alkaline lipase of Aspergillus fumigatus MTTC 9657, International Journal of Food Science and Technology.,49: 1337-1343.

[10] Jan Philipp Schushardt, Micheal Huss, Manuela Stauss-Grabo and Andreas Hahn, 2010. Significance of long-chain polyunsaturated fatty acids (PUFAs) for the development and behaviour of children. Eur. J. Pediatr., vol 169, 149-164.

[11] Shiva Shanker Kaki, Kunduru Konda Reddy, Sanjit Kanjilal and R.B.N. Prasad, 2012. Enzymatic preparation and characterization of Trans-free from palm stearin and natural vegetable oils,JLST, vol 44, no 3.

[12] T.S.V.R. Neeharika, P. Lokesh, K.N. Pransanna Rani, T. Prathap Kumar and R.B.N. Prasad, 2015. Kinetics of enzymatic hydrolysis of methyl ricinoleate, Grasas Y Aceites, 66(4).

[13] Sulaiman AlZuhair, Masitah Hasan, K.B. Ramachandran, 2003. Kinetics of enzymatic hydrolysis of palm oil by lipase. Process Biochemistry., vol 38, issue 8, 1155-1163.

[14] Shan-Wei Tsai, Guang-Huei Wu and Chen-Li Chiang, 1991. Kinetics of enzymatic hydrolysis of olive oil in biphasic organic-aqueous systems. Biotechnology and Bioengineering, vol 38, 761-766.

[15] Michael W. Trosset, March 15, 1997. "Taguchi and Robust Optimization".

[16] Roy R.K., 1990. "A Primer on the Taguchi Method", Van Nostr and Reingold, New York.

[17] Montgomery, Douglas C.,1911. "design and Analysis of Experiment, third edition, Wiley, New York.

[18] Suseela Lanka and J. Naaveena Lavanya Latha, 2015. Taguchi design of experiments for the optimization of lipase production by Emericella Nidulans Daom 222012 isolated from palm oil mill effluent (POME) dump sites, International Journal of Applied Biology and Pharmacetical Technology, vol 6, issue-3.

[19] Baris Sisek and Tayfun Uygunoglu, 2016. Multi-response optimization of polymer blended concrete: A TOPSIS based taguchi application, Construction and Building Materials, vol 117, 251262.

[20] Y.C.Wong, Y.P.Tan, Y.H.Taufiq-Yap and I.Ramli, 2015. An optimization study transesterification of palm oil using response surface methodology (RSM), Sains Malaysiana, 44(2), 281-290.

[21] Nadia Pambou-Tobi, Elmira Arab-Tehrany, Rosalie Kama Niamayoua and Michel Linder, 2015. RSM applied for optimization of deep-fat fried ripe plantain slices and study of oxidation kinetics of oil by a DSC and polar methods, Journal of Food Science Technology.

\footnotetext{
*Corresponding author.

E-mail address: harsha.s@ jyothyit.ac.in
} 